\title{
Teachers' Stances on Cell Phones in the ESL Classroom: Toward a "Theoretical" Framework
}

In the ongoing and constantly expanding discussion surrounding cell phones in the classroom, a theoretical complement to the practical side of the issue is generally lacking. This is perhaps understandable. Many teachers are still trying to deal with the simple presence of cell phones in the class, and managing a classroom in which the presence and use of cell phones is a reality takes precedence over charting some sort of theoretical framework. Yet perhaps it is now time to step back and consider such a framework. I offer just such a consideration, as well as some remarks about which theoretical positions might be most advisable in specific classroom contexts.

Au débat portant sur les téléphones cellulaires en salle de classe, toujours actuel et s'élargissant sans cesse, il manque souvent une composante théorique pour venir compléter le côté pratique. Plusieurs enseignants tentent encore de composer avec la simple présence des téléphones cellulaires en classe, alors la gestion d'une classe où on les utilise prend le dessus sur la planification d'un cadre théorique. Il est peut-être temps, toutefois, de prendre un certain recul et de considérer un tel cadre. J'offre une telle proposition ainsi que certaines remarques par rapport aux positions théoriques les plus recommandables dans des contextes pédagogiques particuliers.

\section{Bothering with Theory: The Symbiosis of Praxis}

Why should teachers be concerned with theory regarding cell phone use in the ESL classroom? Why spend time charting out the theoretical underpinnings of something that is inherently a question of practice? Before proceeding any further, it is important to acknowledge that such questions fall back onto the false dichotomy of "theory" vs. "practice." When teachers choose to do one thing as opposed to another thing in the classroom, they are acting on some implicit principle or stance. Such principles and stances are often not articulated explicitly, but it is generally maintained that it is only good pedagogy to have some reason for what is done in the classroom. This is the theoretical complement to practice that forms the symbiotic relationship often dubbed praxis (Clarke, 1994; Pennycook, 2001; Simon, 1992). Strictly speaking, to avoid the limiting theory/practice dichotomy, it might be better 
to refer to a cycle of thought $\rightarrow$ action $\rightarrow$ reflection that repeats indefinitely in the teaching process (Argyris \& Schön, 1978; Schön, 1983); however, I am content to use the term "theory," so long as it is understood in the sense discussed here.

A theoretical framework can be of value in that it provides a sort of shorthand for making sense of the myriad choices faced in practice. Hence it is instructive to distinguish, for example, between inductive and deductive approaches to approaching a grammar point in class, or between an intuitive-imitative approach to teaching pronunciation and an analytic-linguistic approach. Moreover, a clearly articulated theoretical framework provides a context for substantive research on an issue. At this point, a description of the range of principled choices that teachers might make regarding cell phone use in the classroom is, by and large, lacking. Articles on the subject tend to be pragmatic, focusing on the ubiquity of cell phones in classrooms and suggesting activities using them (see, for example, Pesce, 2013; Read, 2009; Smikle, 2013). Prensky's (2001) distinction between digital natives and digital immigrants is sometimes cited (Barter \& Abdulabbas, 2012; Haynes, 2010; Smikle, 2013; Stockwell, 2010) as a theoretical underpinning in this regard. However, Prensky's distinction is over a decade old-ages in a hyperspeed digitized world - and as a result has lost much of its currency. Many of these so-called digital natives are today's teachers, yet the distinction as presented is based on the facile notion that teachers are digital immigrants and students digital natives. In any case, the theoretical framework that I propose here is in no way profitably informed by Prensky's oft-invoked distinction.

The main reason that a principled framework with respect to teachers' stances on cell phones is lacking is that thus far such a framework has not been the concern of most teachers and researchers. Jarvis and Achilleos (2013), for example, focus on the use of cell phones in L2 learning outside the classroom and advocate a change of acronym from computer assisted language learning (CALL) to mobile assisted language use (MALU). Kukulska-Hulme (2009) examines the usefulness of cell phones in task-based learning, specifically as a way of linking what is taught in the classroom to learning outside the classroom. Using cell phones in the classroom helps connect learning to students' immediate surroundings; they are particularly effective in supporting collaborative learning in small groups. Kukulska-Hulme (2009) suggests using the texting function on phones to build vocabulary. For example, learners can text both fellow students and the teacher about the meanings of words. They can access various websites that can link learning to interactive games and to sites that might promote social awareness and engagement. ${ }^{1}$ Kiernan and Aizawa (2004) carried out a study investigating the extent to which cell phones can be of use in the language classroom, finding that texting, accessing e-mail for practice reading and writing, and even using phones for speaking exercises can all be effective activities in the language classroom. Stockwell $(2010,2012)$ and Ballance (2012) engage in a thought-provoking 
dialogue on the comparative merits of PCs (personal computers; e.g., more user-friendly keyboards, larger screens) and cell phones (e.g., touch-screen technology, accessibility, and convenience) as resources for assigned CALL tasks. Bibby (2011) conducted a study on students' preferences between PCs and cell phones in language learning, with cell phones the apparent favourites. For certain activities (such as the ones mentioned above), students' cell phones would seem to be preferable to stationary desktop computers.

The preceding are all vital and much-needed studies and discussions, yet they do not deal explicitly with the issue of teacher attitudes to cell phone use in class. Interestingly, this issue has been investigated-although not in the specific manner proposed in this article-to some extent in the field of education in general (see, for example, Baker, Lusk, \& Neuhauser, 2012; Burns \& Lohenry, 2010; Campbell, 2006; Fang, 2009; Tindell \& Bohlander, 2012). Clearly, the issue of mobile phone use in class is of importance for a wide range of teaching professionals. Yet there are issues specific to the TESL field in particular. For example, many ESL students rely on their mobile phones as (translation and English-English) dictionaries. Given that most mobile phones also have Internet access, they can be drawn upon to alleviate crosscultural difficulties. For example, students can do a quick Google search to access background information on a cultural point causing confusion among classmates from different backgrounds. Students can easily access images and photos online to better explain to classmates some aspect of life in their home countries (e.g., cuisine, religion, fashion). In addition, there are often external personal factors specific to ESL learners that make them more insistent on keeping their phones with them (perhaps beside them on their desks) at all times so that the devices are within visual and auditory range. For example, international students often suffer from homesickness, and the presence of their cell phones might offer some assurance that they can be contacted (for instance, in case of an emergency) by family members at home. Domestic ESL students who are new immigrants might want their phones on hand in case they receive a call regarding accommodation or employment opportunities. These psychological factors thus complicate policies on cell phones in the class. Thus, while those in the TESL field would do well to note studies conducted in the wider education field, there are ESL-specific issues that demand a perspective that takes these issues into account.

An active ESL-specific approach to the question of cell phone use in the classroom is thus warranted. Such an approach certainly involves further studies of the sort cited above, and practitioners should remain current on such research. However, an active approach in this regard should also include a specification and justification of any given classroom stance on student cell phone use. To this end, I want to examine what the thinking might be in a specific situation when a teacher deems the use of cell phones "appropriate" for a particular activity or, alternatively, what principles might be decisive when phones are deemed "inappropriate" for an activity. The dual 
objective here is (a) to make explicit the pivotal concerns and commitments that underpin classroom practices with respect to cell phone usage and (b) to set the stage for further reflection (which, as indicated, should include future research studies) upon these concerns and commitments, thereby rendering those practices more effective.

\section{Provisional Sketch of Some Theoretical Stances}

In this section I present brief descriptions of the theoretical commitments that might underlie various attitudes toward cell phone use in the classroom. By cell phone use I refer to a wide variety of classroom activities that employ and/ or require the use of these mobile devices. These include using cell phones to perform web searches; utilizing recording functions; working with social media; and using the cell phone as a dictionary, both translation and EnglishEnglish. Also included are any nonlearning activities that students engage in with their cellular devices (texting friends and family, surfing the Web, etc.) in the classroom; these are clearly also involved in the classroom management aspect of the issue. While there are other devices that can be used in the classroom (such as iPads, tablets, and laptops), the current discussion is restricted to cell phones since they are the most ubiquitous (and therefore relevant) devices.

Clearly, a factor that must be taken into account is that there might be a technological divide with respect to cell phone use. That is, some students might have the latest smartphone, others might have older phones with fewer functions, and some might not have mobile devices at all. Of course, even if not all students have access to cell phones, they can often work in pairs to complete tasks. In any case, the technological divide question is a pivotal consideration that will inform a teacher's choice of classroom cell phone use policy.

This is a programmatic exercise. Although I think most of the approaches I describe are, to some degree and in some form, employed in ESL classrooms by teachers, these descriptions do not report what teachers do, but rather provide a provisional framework for thinking about what teachers do. The terminology that I employ in this framework to describe the various stances is not used in the literature on the subject precisely because, as pointed out above, specifying adherence to any such stances has not thus far been an objective in contributions to the literature. My suggestion is that specifying the operative stance in a given learning context can more clearly justify, and therefore make more effective, pedagogical choices within that context.

To begin with, maintaining a strict "no cell phones" policy in the ESL classroom can be called an absolutist approach to the issue at one end of a continuum (prohibitionism). At the other end is the contrasting absolutist approach (i.e., permissivism) (see Figure 1). 


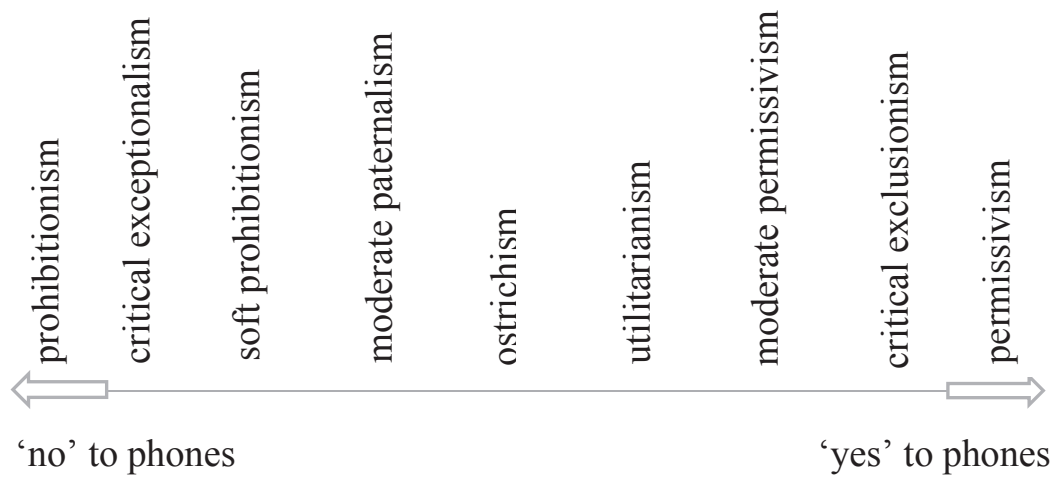

The prohibitionist forbids the use of cell phones in the language class, considering their presence to be a distraction and an impediment to learning. Not necessarily a neo-luddite, the prohibitionist nonetheless deems the devices at issue to have no place in the classroom. This might be presented as a principled pedagogical stance and not simply a "teacher knows what's best" policy. A punitive element might be incorporated into this approach. For example, if participation is part of the assessment for the course, a student might be penalized for violation of the "no cell phones" policy.

The opposing absolutist approach, permissivism, embraces and encourages the use of cell phones in class. The reasons for this opening of the gates, as it were, may be many and varied. Teachers working from a permissivist approach may be convinced (still subscribing to Prensky's dichotomy) that their students are a group of digital natives who can only thrive if permitted to enlist the technology they consider to be a necessary part of life. As such, pedagogical commitments might hold sway here. Alternatively, issues of social justice may be decisive. Who, after all, is the teacher to divest studentsautonomous individuals - of their right to use their phones when and where they see fit?

These absolutist approaches act as bookends to another half-dozen approaches that represent the range of attitudes that seem to fall between the two. Critical exceptionalism operates against a backdrop of prohibitionism. According to this stance, cell phone use is sometimes permitted/encouraged when there is good reason to do so. Put simply, while a prohibitionist stance is generally maintained, exceptions to the no cell phones policy do occur. The 
key is that these exceptions are principled and based upon a critical evaluation of the specific needs of the class. This position employs what we might call a "problematizing practice" (Benesch, 2009; Pennycook, 2001); the teacher engages in a continual examination and critique of a given policy ${ }^{2}$ and, when warranted, suspends it (such suspensions can involve the use of cell phones in any of the ways mentioned above). With regard to classroom management, the teacher perhaps recognizes the negative affective variables that can result from prohibiting cell phones. So, while a cell phone ban may be deemed necessary to create an effective learning environment, the teacher acknowledges that students might become anxious and even resentful because of separation from their cell phones, have difficulty focusing, and therefore learn less effectively. Allowing for exceptions to the no cell phones policy then might alleviate these affective issues; it also acknowledges that there can be legitimate pedagogical uses for cell phones in class and that to maintain an absolutist approach in this regard is unreasonable. Clearly, a number of principles underlie this approach.

Soft prohibitionism, precisely because of its "softness," is farther on the continuum from prohibitionism than is critical exceptionalism. A teacher adopting a soft prohibitionist policy espouses a general no cell phones rule, but maintains no principled policy with respect to violations of the so-called rule. Hence there is nothing to be enforced. The soft prohibitionist may feel that strict enforcement of the no cell phones policy is unfair; this would depend on the personality and teaching style of a particular teacher. Or there could be a latent, unarticulated critical exceptionalist approach underlying this stance. In any case, there is no consistent justification for suspensions of the prohibition on cell phones. Given the possible outcomes of soft prohibitionism, it could unintentionally morph into any number of other approaches closer to the permissivist end of the continuum.

Moderate paternalism represents a modulated prohibitionist stance. The moderate paternalist is perhaps quite convinced that cell phone use should be controlled to some degree and is prepared to intervene when such use interferes with immediate classroom objectives. What distinguishes paternalism from a critical exceptionalist approach is that paternalistic intervention is based more upon the teacher's sense of what is needed (in terms of successfully achieving instructional objectives or in terms of classroom management issues) than it is upon a joint critical analysis (i.e., one incorporating both the teacher's and the students' perspectives) of what might constitute a legitimate exception to the prohibition on cell phone use. Moderate paternalism thus represents a top-down policy, as opposed to a bottom-up approach.

Occupying the middle of the continuum, ostrichism can occur under the guise of several other approaches. Strictly speaking, this attitude is not a principled stance at all; rather, the teacher in this case simply ignores the issue of cell phones in the classroom. At no point is there a putative classroom policy or default approach to the issue. 
Utilitarianism seems to be the position most commonly represented in the limited literature on the subject (Hockly, 2013; Kiernan \& Aizawa, 2004; Pesce, 2013; Read, 2009; Smikle, 2013; Viswanathan, 2012), although, once again, this is not a term used by the authors. This stance ought not to be equated with ostrichism. There is indeed a principle underlying the utilitarianism approach: that ubiquitous phones are best dealt with by being put to use in the service of language learning and student engagement. What varies with this approach is the extent to which the teacher has truly embraced the technology as a legitimate pedagogical resource. A teacher's attitude here might be characterized by resignation; that is, the teacher might accept rather than embrace the technology. On the other hand, the teacher might genuinely believe that the effective and directed use of cell phones in class plays a vital part in the learning process. Anecdotal evidence suggests it is also a position often adopted by teachers in the language classroom.

Moderate permissivism is a modulated permissivist stance. It favours the notion that students should be free to do as they see fit with their cell phones over the notion that phones serve a utilitarian function. Although it is difficult to specify precisely whether this in fact represents a distinctive approach, I include it here as a reminder that there may be a more nuanced (perhaps ambivalent) stance somewhere between a more overt utilitarian stance and the permissivist end of the continuum.

Critical exclusionism (basically, the mirror image of critical exceptionalism) is set against a backdrop of permissivism. Just as the teacher adopting a critical exceptionalist approach arrives at points where exceptions are made to the prohibition on cell phones, so the critical exclusionist arrives at points where it seems best to overtly exclude cell phones from the resources utilized in the ESL classroom.

\section{Evaluating the Stances}

A complete evaluation of these stances is beyond the purview of the present discussion. However, I would like to offer some preliminary observations in this regard with a view to demonstrating the general applicability and usefulness of the proposed framework. By an "evaluation" of the stances, I mean a consideration of the pros and cons and the applicability of any given approach depending on a particular context or set of circumstances. What works best for a particular class or for any given level might change depending on specific contextual factors (for example, class size, lesson objectives for the day, progress through the course curriculum, the mood of the class as a group on a particular day); hence, a teacher might move from one stance to another when warranted by these factors.

A tentative suggestion, however, is that absolutist stances should be regarded with some caution. The problem is that to adopt an absolutist approach is to essentially deny that the use of cell phones needs to be dealt 
with in the classroom: the issue has been defused because phones have either been banished (prohibitionism) or embraced (permissivism). However, in both cases, the problem of how the language learning process is affected by the presence or absence of cell phones remains unaddressed. Even if phones are putatively no longer in use in the classroom, crucial affective variables still come into play. Students often remain aware of and distracted by their cell phones even when the devices have been stored out of sight, with the result that they are not entirely engaged in the learning process. In addition, prohibitionism seems closed to the possibility that cell phones, under the right circumstances, might be a legitimate learning resource. On the other hand, if cell phone use is unchecked, the teacher fails to consider how such behaviour alters the class environment and, from a pedagogical standpoint, the possibility that in some circumstances learning might be more effective without cell phones. Therefore, it appears unadvisable to adopt an absolutist approach with respect to phone use in class. Research would be required to confirm these preliminary intuitions.

Aside from the concerns pertaining to absolutist stances, all the other approaches suggested above appear to have merit. As an example, I would like to consider the context of an advanced college English for academic purposes (EAP) reading class and briefly discuss which of the outlined stances might be appropriate in this type of ESL class and in what circumstances. There are a wide variety of ways in which a teacher might decide to employ cell phones in the classroom to support EAP learning objectives (and many of these uses might be applicable to classes in other contexts, as well). For example, students can read Twitter feeds from relevant figures or perform online searches for information related to classroom topics or assignments. Texting can be utilized for writing practice. LinkedIn has become an essential element of networking in the contemporary job market, and visiting or setting up LinkedIn pages can be a very productive exercise for students. E-mail is a useful learning tool; it remains an essential medium of academic communication and one that international students pursuing future studies in a Canadian postsecondary setting will likely have to become accustomed to. ${ }^{3}$ The recording and camera functions on students' phones can be utilized for speaking activities, interviews, or presentations. A plethora of vocabulary practice activities - including Academic Word List (AWL) practice exercises ${ }^{4}-$ can be accessed using student smartphones or iPhones. There is also a growing number of useful apps that students may be able to access with their mobile devices. Activities employing apps support any number of academic skills and learning objectives (such as conducting surveys, summarizing, creating graphs and charts, editing, blog and wiki writing, to name just a few) and can be incorporated in effective ways into either individual or group work in the EAP classroom (cf. Carrington, 2013). ${ }^{5}$

These overtly pedagogical (learning) uses of cell phones in the EAP classroom need to be distinguished from nonlearning uses. Game apps (i.e., 
those with no language learning purposes) are an example of such a nonlearning use of phones. Other examples include personal Facebook pages, personal use of Twitter (or other social media), and texts to friends. Actual phone calls can clearly also be a disruption and distraction in the classroom. These nonlearning uses of phones are, of course, by no means restricted to EAP classrooms, but when combined with some of the aforementioned affective variables prominent in many ESL classrooms (separation from family for international students, various issues affecting domestic students who are new immigrants), they can present considerable challenges to effective learning.

An EAP teacher's stance toward cell phones in the classroom is thus informed by their potential (learning and nonlearning) uses, and we can characterize such stances in terms of the continuum of theoretical attitudes sketched above. For example, a critical exceptionalist approach might be preferable in an advanced EAP academic reading course. In my experience, for example, students can become overreliant on the translation function available in the electronic dictionaries available on their cell phones. Translation is indeed a useful vocabulary learning tool, but other reading strategies-such as inferring meaning from context, skimming for the main idea, scanning for specific information-should also be promoted. With this in mind (and also bearing in mind the uses that can be disruptive to the class), a teacher might prohibit cell phone use in the classroom, making exceptions to this general "no phones" policy when the learning objective is actively supported by cell phone use (for instance, doing a search for a synonym or for an explanation of an idiom, or translating key AWL words). Again, other contextual factors might play a role here. The teacher may be aware, for example, that only half the students own mobile phones with the relevant functions; in this case, phones might be prohibited except for occasional partner or small-group activities utilizing the devices.

Varying EAP classroom conditions and learning objectives might prompt a teacher to adopt a different stance toward cell phones. A utilitarian stance that tends more toward the permissivist end of the proposed continuum might be deemed appropriate if, for example, all the students in the class own mobile devices that support learning activities. Activities could then be initiated with less formality, perhaps even spontaneously if warranted. By contrast, a teacher might decide that, given certain decisive classroom factors, a strict prohibitionist stance is warranted. For example, a technological divide among students might adversely affect the classroom culture, or a number of students may simply not be able to refrain from nonlearning uses of their phones. After having weighed the advantages and disadvantages of phone use in the classroom, a teacher might decide that it is best to maintain an outright ban on the devices (however, as indicated, whether such a stance is advisable is another question altogether). 


\section{Closing Remarks}

Specific contextual factors will have an impact on the stance to which a teacher adheres. No learning environment is static or monolithic, and a teacher will adopt different stances - moving back and forth along the proposed continuum - within the same level and even with the same group of students as specific circumstances warrant. The proposed framework provides a means of identifying and isolating the principles and attitudes that underlie a given stance, and hence of evaluating which one might be most effective in any given classroom context.

Empirical research is needed to determine whether the range of stances I have proposed here can be effectively used as a framework for subsequent research in the TESL field. Nonetheless, the preceding discussion can perhaps aid in initiating a conversation about why teachers do what they do with respect to cell phones in their classrooms. By a conversation about "why," I mean a discussion of the principles and commitments that are cited to support a given stance adopted with respect to classroom cell phone use in a particular learning context. Such a conversation might be carried out in the pages of professional journals, or at conferences, or more informally in faculty rooms in ESL departments. Whatever the context, it is a conversation that needs to take place.

\section{Acknowledgements}

I thank Jean Grindley and Brett Reynolds for helpful comments on early drafts of this article. I would also like to thank the editor and anonymous reviewers of TESL Canada Journal for their constructive feedback on later drafts.

\section{The Author}

Jeff Brown holds an MA and a PhD in philosophy and a postgraduate certificate in TESL. He teaches in the School of Liberal Arts and Sciences at Humber College in Toronto.

\section{Notes}

1 An example provided by Kukulska-Hulme-and a website that I have used to great effect in the language classroom - is the excellent www.freerice.com.

2 It should be noted that Benesch's and Pennycook's remarks are more general and not directed at cell phone use specifically.

3 E-mail "pragmatics" is an area in which many - though not all-ESL students struggle and for which explicit instruction is often required.

4 See, for example, http://www.englishvocabularyexercises.com/AWL/id17.htm

5 It must be noted that Carrington (2013) explicates his "padagogy," as the name suggests, with iPads in mind (see http://www.unity.net.au/padwheel/padwheelposter.pdf). However, as pointed out, many apps can now be accessed via cell phones, and much of Carrington's taxonomy is now applicable to cell phones. Mobile communication devices are constantly evolving; some students will have access to the latest apps and some will not. This only further underscores the point that teachers must remain flexible and willing to take into account such variables when dealing with this issue in the classroom. 


\section{References}

Barter, B., \& Abdulabbas, W. (2012). ESL teachers' perceptions of using technology in their teaching. Slideshare. Retrieved from http://www.slideshare.net/brandybarter/esl-teachersperceptions-of-using-technology

Argyris, C., \& Schön, D. A. (1978). Organization learning: A theory of action perspective. Reading, MA: Addison Wesley.

Baker, W. M., Lusk, E. J., \& Neuhauser, K. L. (2012). On the use of cell phones and other electronic devices in the classroom: Evidence from a survey of faculty and students. Journal of Education for Business, 87(5), 275-289.

Ballance, O. J. (2012). Mobile language learning: More than just "the platform." A commentary on Glenn Stockwell's "Using mobile phones for vocabulary activities: Examining the effect of the platform." Language Learning \& Technology, 16(3), 21-23.

Benesch, S. (2009). Critical English for academic purposes: Theory, politics, and practice. New York, NY: Routledge.

Bibby, S. (2011). Do students wish to "go mobile"? An investigation into student use of PCs and cell phones. Computer-Assisted Language Learning and Teaching, 1(2), 43-54.

Burns, S. M., \& Lohenry, K. (2010). Cellular phone use in class: Implications for teaching and learning a pilot study. College Student Journal, 44(3), 805-810.

Campbell, S. W. (2006). Perceptions of mobile phones in college classrooms: Ringing, cheating, and classroom policies. Communication Education, 55(3), 280-294.

Carrington, A. (2013). The pedagogy wheel V2.0: It's all about transformation and integration. Retrieved from http://www.unity.net.au/padwheel/padwheelposter.pdf

Clarke, M. A. (1994). The dysfunctions of the theory/practice discourse. TESOL Quarterly, 28(1), 9-26.

Fang, B. (2009). From distraction to engagement: Wireless devices in the classroom. EDUCAUSE Quarterly, 32(4), 4-9.

Haynes, J. (2010). DSL: Digital as a second language. Everything ESL. Retrieved from http:// everythingesl-everythingesl.blogspot.ca/2010/01/dsl-digital-as-second-language.html

Hockly, N. (2013). Mobile learning. ELT Journal, 67(1), 80-84.

Jarvis, H., \& Achilleos, M. (2013). From computer assisted language learning (CALL) to mobile assisted language use (MALU). TESL-EJ, 16(4). Retrieved from http://www.tesl-ej.org/wordpress/issues/volume16/ej64/ej64a2/

Kiernan, P. J., \& Aizawa, K. (2004). Cell phones in task based learning: Are cell phones useful language learning tools? ReCALL, 16(1), 71-84.

Kukulska-Hulme, A. (2009). Will mobile learning change language learning? ReCALL, 21(2), 157-165.

Pennycook, A. (2001). Critical applied linguistics: A critical introduction. New York, NY: Routledge.

Pesce, C. (2013). What you can do with a cell-phone: 7 great ESL activities. Busy Teacher. Retrieved from http://busyteacher.org/6955-7-great-esl-cell-phone-activities.html

Prensky, M. (2001). Digital natives, digital immigrants. On the Horizon, 9(5). Retrieved from http://www.marcprensky.com/writing/Prensky\%20-\%20Digital\%20Natives,\%20Digital\%20 Immigrants\%20-\%20Part1.pdf

Read, D. (2009). Please turn on your mobile phones. Mobile ESL. Retrieved from http://mobileesl. blogspot.ca/2009/11/please-turn-on-your-mobile-phones.html

Schön, D. A. (1983). The reflective practitioner: How professionals think in action. New York, NY: Basic Books.

Simon, R. I. (1992). Teaching against the grain: Essays towards a pedagogy of possibility. London, UK: Bergin \& Garvey.

Smikle, L. (2013). Sold on cell phone activities. Contact, 39(1), 11-14.

Stockwell, G. (2010). Using mobile phones for vocabulary activities: Examining the effect of the platform. Language Learning \& Technology, 14(2), 95-110. 
Stockwell, G. (2012). Working with constraints in mobile learning: A response to Ballance. Language Learning \& Technology, 16(3), 24-31.

Tindell, D. R., \& Bohlander, R. W. (2012). The use and abuse of cell phones and text messaging in the classroom: A survey of college students. College Teaching, 60(1), 1-9.

Viswanathan, R. (2012). Augmenting the use of mobile devices in language classrooms. ComputerAssisted Language Learning and Teaching, 2(2), 45-60. 